\title{
Modern Swahili: the integration of Arabic culture into Swahili literature
}

\section{Hanah Chaga Mwaliwa}

Hanah Chaga Mwaliwa is a lecturer of Swahili language and linguistics in the Department of Kiswahili, University of Nairobi, Nairobi, Kenya.

Email: mwaliwach@gmail.com

DOI: dx.doi.org/10.17159/2309-9070/tvl.v.55i2.1631

\section{Modern Swahili: the integration of Arabic culture into Swahili literature}

Due to her geographical position, the African continent has for many centuries hosted visitors from other continents such as Asia and Europe. Such visitors came to Africa as explorers, missionaries, traders and colonialists. Over the years, the continent has played host to the Chinese, Portuguese, Persians, Indians, Arabs and Europeans. Arabs have had a particularly long history of interaction with East African people, and have therefore made a significant contribution to the development of the Swahili language. Swahili is an African native language of Bantu origin which had been in existence before the arrival of Arabs in East Africa. The long period of interaction between Arabs and the locals led to linguistic borrowing mainly from Arabic to Swahili. The presence of loanwords in Swahili is evidence of cultural interaction between the Swahili and Arabic people. The Arabic words are borrowed from diverse registers of the language. Hence, Swahili literature is loaded with Arabic cultural aspects through Arabic loanwords. Many literary works are examples of Swahili literature that contains such words. As a result, there is evidence of Swahili integrating Arabic culture in its literature, an aspect that this paper seeks to highlight. Keywords: Arabic, cultural integration, linguistic borrowing, Swahili literature.

\section{Introduction}

Swahili is a term used to refer to a society of people living along the coast of East Africa whose native language is Kiswahili, a Bantu language spoken mainly in East Africa and beyond. It is spoken by well over 200 million people within Africa in Tanzania, Kenya, Uganda, Democratic Republic of Congo, Rwanda, Burundi, Mozambique, Zambia and Malawi (Massamba et al. 2). Swahili functions as the official language in Kenya, Tanzania and Burundi. It is also used as the national language in Kenya, Tanzania, Uganda, Rwanda and Burundi. Mazrui and Mazrui state that Swahili functions as a medium of trade, religion, education, civil administration, practical politics and collective bargaining throughout the East African region (160). In other words, Swahili is the lingua franca of the entire region East and Central Africa. Choge states: "Kiswahili is a regional language in East Africa countries where it wears several hats as a vernacular, national and official language, lingua franca and a vehicular in various spheres of life" (172). Prior to the arrival of foreigners on the East African coast, the Swahili led their life with their own religion, beliefs, economic activities, language and social activities as their culture. They had their name as a people before it was changed by the Arabs to Swahili. "[T]he name 'Swahili' is derived 
from Arabic denoting 'language of the coastal people'" (Mazrui and Mazrui 170).

Arabic, on the other hand, is a Semitic language spoken by 350-400 million people in the Arab world and beyond. Akidah states that Modern Standard Arabic is the standard Arabic dialect that is spoken beyond geographical boundaries (2). In this article, "Arabic" refers to Modern Standard Arabic. The word Arab refers to a society of people with Asiatic origin speaking a Semitic group language called Arabic. The Arabs travelled to the East African coast by sea and settled, where they met and mingled with the Swahili people. When Arabs came to the East African coast, they also had their own way of life. They came to Africa mainly to do trade. As the Arabs traded in East Africa, they intermarried with the Swahili people. The Arabs also introduced their religion to the Swahili people that led to the majority of Swahili converting to Islam. In the long period of interaction between the Arabs and Swahili people, many Arabic words were borrowed into Swahili, thanks to cultural integration.

Prior to the arrival of Arabs to the East African coast, in Swahili culture, children belonged to their mother and not father; a kind of matriarchal system. In addition, spirits were given feminine names such as Mwana Chambi, Mwana Mkisi and Mwana Mtwapa (Chiraghdin and Mnyampala x). The Arabs came to East Africa with a culture that differed from that of the Swahili. One of the major differences between Arabic and Swahili culture was religion. Arabs came with their Islamic religion which they introduced to the Swahili people. Another cultural aspect is the language; over a period of contact between Arabs and Swahili, intermarriage took place, trade expanded, and Islam rapidly spread along the coast of East Africa, resulting in cultural integration. The Swahili people adopted much of Arabic cultural aspects such as their cuisine, manner of dress, religion, education, trade and art. In the process, Arabic words also found their way into Swahili through linguistic borrowing. As Boesch says, "culture has the potential to change rapidly if a new social model becomes available" (83). This is what happened to Swahili culture; as a result of social integration between the Swahili and Arabs, Swahili culture has changed by adopting Arabic cultural aspects. These borrowed cultural aspects are reflected in Swahili literature through loanwords from Arabic.

In this study, I used purposive sampling of select Swahili literary works from two genres, that is, poetry and prose. The two genres were selected on the basis that they are more readily available in print form compared to other genres such as drama. The criteria used to select these works was the use of loanwords in the texts, as well as the time of their publication. I wished to investigate both classical and modern literary works in Swahili to show how loanwords have featured in these works. In poetry, I selected Inkishafi (1980) by Sayyid Abdalla A. Nassir, and 'Sikate Tamaa (1980) by Said A. Mohamed to represent classical authors; while Bara Jingine (2001) by Kithaka wa Mberia represents modern authors. I also selected the novel Adili na Nduguze by Shaaban Robert (1952) representing classical authors and Siku 
Njema (1996) by Ken Walibora representing modern authors. Sikate Tamaa (Said A. Mohamed) and Adili na Nduguze (Robert) are Tanzanian Swahili texts (see Wamitila 123), whereas the rest of the texts are Kenyan texts.

I identified loanwords from Arabic used in the selected works. I then categorized the loanwords according to their respective registers, that is, religion, economy, administration, education, literature and social culture. The identified sample of loanwords selected from the mentioned literary works are attached in the appendix to this paper.

\section{Linguistic borrowing from Arabic to Swahili}

Swahili and Arabic came into contact in the early years of the $10^{\text {th }}$ century, when Arabs travelled and settled along the coast of East Africa between the $9^{\text {th }}$ and $10^{\text {th }}$ centuries (Harries 224-5). According to Chiraghdin and Mnyampala, one of the reasons Arabic loanwords are more prevalent in Swahili, as compared to loanwords from other languages such as Portuguese, Persian, French, English and German, is that the Arabian Gulf is the closest to the coast of East Africa. Due to this proximity, Arabs made frequent journeys to and from Africa and, therefore, its speakers interacted most with the Bantu people (mostly Swahili) along the East African coast (1). The Arabs' and Swahilis' long history of contact led to inter-marriage and borrowing of words mainly from Arabic to Swahili. Mazrui and Mazrui state that the contact between Swahili and Arabs was not merely religious and cultural, but also economic (126). Polome alludes to the fact that the Swahili people shared the faith and culture of Arabs (10). According to Chiraghdin and Mnyampala, the second reason why Swahili borrowed from Arabic is that many Arabic words were used in the teaching of the Islamic religion (5). From this, one can see that the learning of Islam by the Swahili contributed to cultural contact and therefore, to linguistic borrowing largely of religious terms from Arabic to Swahili. Examples of loanwords borrowed in the domain of religion include: dini (religion), dhambi (sin) and jahanam (hell). Apart from religion, the Arab-Swahili interaction in trade also contributed to linguistic borrowing of words such as bidhaa (products), dhahabu (gold), fedha (silver) and khasara (loss). Cultural integration between the two groups of people led to borrowed words such as dunia (world), amani (peace), taji (crown) and rafiki (friend). There are also words related to the arts that were borrowed from Arabic to Swahili; for instance, fasihi (literature), sanaa (art), utenzi (long poem), ubeti (stanza) and hadithi (story).

Indigenous African languages have borrowed from other languages, especially English, French and Swahili. Thus, linguistic borrowing does not reduce the status of a language; rather it helps the language to expand its vocabulary and therefore its functional dimension. There are two main reasons as to why linguistic borrowing occurs; these are need and prestige (Anttila 155). Mwaliwa asserts this about Swahili 
by stating that Swahili borrowed items from Arabic to meet certain functional needs (50). This applies especially to words found in the domain of religion (Islam) as stated by Mazrui and Mazrui, "Swahili developed within Islamic culture and borrowed many Arabic words of Islamic religion" (174). Examples of words borrowed from Arabic to Swahili to cater for new religious concepts include: Ramadhan (holy month of Muslim fast), Idd (Muslim festival) and Madrasa (Islamic religious school). These were borrowed into Swahili to represent new concepts that hitherto were not present in Swahili. Some words were borrowed into Swahili to cater for concepts that are not new to the community, for instance: Mola (God), Harusi (wedding) and Maradhi (diseases). These words were borrowed into Swahili for the reason of prestige, given that there are indigenous words that represented them prior to the arrival of Arabs. The Bantu Swahili words for Mola, Harusi and Maradhi are Mungu (God), ndoa (wedding) and magonjwa (diseases), respectively.

When words are borrowed into a certain language, they either get adapted or adopted in terms of their structure. Mwaliwa affirms that most of the Arabic words were adapted to conform to the linguistic structure of Swahili (285). This means that the loanwords were structurally changed to fit into the structure of Swahili. Words that hitherto had Arabic syllable structures were modified to conform to Swahili syllable orientation especially CV (consonant and vowel). For instance, the words birika (kettle), askofu (bishop) and adhuhuri (noon) have been changed to adapt to the Swahili structure. Yet, a few words have been rendered into Swahili as they were in Arabic having closed syllables, for example: maktaba (library), labda (perhaps) and maalum (special). In addition, Swahili adopted three Arabic sound segments through borrowed words; the sound segments $/ \mathrm{gh} /, / \mathrm{dh} /$ and $/ \mathrm{th} /$ in words such as ghadhabu (wrath), ghafla (suddenly), dhiki (distress), dhambi (sin), thawabu (reward) and thibitisha (confirm) have now become part of Swahili phonology. Such borrowed words are used by the authors of Swahili literature under study.

\section{Overview of Swahili literature}

Swahili has been used as a medium of communication in written texts including literary works. Educational books are available for teaching Swahili as a language to pupils and students in primary and secondary levels, respectively. In addition, literary works in poetry, drama, short stories and novels are also available in large numbers. Several authors from around the region have produced literary works using Swahili, such as Shaaban Robert, Said Ahmed Mohamed, Abdilatif Abdalla, Mohamed Suleiman Mohamed, Zainab Burhani, Shafi Adam Shafi, Alamin Mazrui, Euphrase Kezilahabi, Katama Mkangi, Emmanuel Mbogo, Kithaka wa Mberia, Mwendah Mbatia, John Habwe, Kyallo Wadi Wamitila, Ken Walibora and many more. These literary works have been read widely across the region particularly in schools, colleges and universities offering Swahili and its literature as subjects. Even though 
English literature is also prevalent in the East Africa region, Swahili literature is making its presence felt in the contemporary period. This is an indication that Swahili literature is thriving in East Africa particularly in Kenya and Tanzania (Choge 183).

Evidence of written literature in Swahili dates as far as the $17^{\text {th }}$ century with the oldest surviving manuscript called Hamziya that was written in 1652 (Amidu 114). Authors of both traditional and modern Swahili literature have contributed immensely to the development of Swahili literature in the region. First, they have contributed towards the widespread use of Swahili in the region. More so, the use of literary expressions such as idioms, proverbs, vocabulary and so on, has been inherited by the community through Swahili literature. Swahili culture has also been well explained and understood by the readership in this region thanks to Swahili literature written by scholars. The Swahili way of life and especially how modernity is infiltrating Swahili culture is well captured in many of the literary works in the region.

\section{Analysis of the selected Swahili literary works}

Inkishafi (1980), which literally means soul-searching, was authored by Sayyid Abdalla A. Nasiri. This is a long poem consisting of seventy-nine stanzas believed to have been composed by the author between 1810 and 1820 A. D. (wa Mberia 92). It describes Swahili life on Pate Island. This text revolves around the theme of mortal life in which the author advises us to live according to God's will and shun earthly glory that is only temporary. The poem depicts the world as a dangerous place, unclean and deceptive to man, which promises man water, only for man to realize that there was no water, but a mirage. He contends that if man does not shun evil and live according to the will of God, he will end up in hell. The poet artistically paints three pictures to drive home his message. In the first part, the poet paints a picture of Pate Island basking in wealth and glory. Here, we see a picture of great men living in prosperity as is characterised by gold and silver, riches and power, living in splendid houses, and being full of joy and merriment daily (wa Mberia 93). The second part of the poem depicts Pate Island in ruins and desolation. The wealth and glory are no more to be found on the island. Instead it is depicted that bats, spiders, owls, vultures, doves, cockroaches and crickets have taken over the place (wa Mberia 94). According to the poet, Pate Island's downfall was because of pride that was exhibited by the inhabitants during the earlier days of glory. Since they did not take heed to God's way of life, they ended up in punishment through death. The third part of the poem gives a picture of hell, where the poet describes the various stages of hell with its horrors and agonies (wa Mberia 95). According to the poet, those who refuse to live in line with God's will, end up in hell where there is torture by fire after death. The poem is influenced by Islamic teachings, the author being an Islamic scholar and in line with teachings as indicated in the Islamic Holy book, the Quran. 
Inkishafi makes use of loanwords in the religious register such as bismillahi and dhambi. The poet introduces the name of God by using an Arabic loanword at the start of his poem. This tradition is common in many epics; being Muslim, the poets always began their compositions in this religious manner, for instance, Utenzi wa Fumo Liyongo also begins in the same way. The effect of bismillahi, which contains the name of God (Allah), is that it gives God the first and lofty place in the poem. The poet acknowledges God as the one who gives him inspiration in the creation of the poem. This loanword is used in the first stanza; in fact, it is the first word of the whole epic. This shows the importance given to God by the poet. There is no equivalent of this loanword in Swahili, given that Allah is the God of Muslims who was introduced to the Swahili by the Arabs. This tradition was then passed over to generations that followed to date. The loanword dhambi (sin) is used in stanza 71 of the epic where the poet talks of an oppressor who in the end is punished. In line 3 of the verse, the poet says that the oppressor will be punished with all the sins committed by those he oppressed. In other words, evil people will finally pay for their sins. In this poem, the poet equates any form of injustice with sin, which is punishable on earth and in the afterlife by God. Given that the author of Inkishafi is Muslim, he makes use of these words knowing that his audience, which was initially Muslim, understands them. These loanwords are frequently used in the religious domain to represent Islamic concepts that bring together people from the two communities, in this case Arabs and the Swahili. An equivalent word for dhambi in Swahili is kosa, which means a mistake or violation. However, the author chooses to use the Arabic loanword dhambi instead of kosa. In my view, the reason for this choice is the intensity of the word dhambi-the mistake connoted by dhambi is graver compared to the one connoted by kosa. Moreover, the loanword dhambi has a religious connotation, as it means breaking of the laws of God, which leads to certain consequences. The author aimed at depicting how the oppressor violated God's law through injustice, and the appropriate word was dhambi.

Loanwords in an economic register such as fedha and dhahabu are used in Inkishafi. Although the text centers around religious themes, it also contains words that are commonly used in trade among Arabs and the Swahili people. In stanza 34, the word wakwasi refers to the rich or affluent, who possess a lot of wealth. The poet has used this Swahili word to paint a picture of very rich people who lived in Pate Island in those days of glory. The loanwords fedha and dhahabu are used in the last line of the verse, referring to gold and silver respectively: precious goods possessed only by rich people. This shows how wealthy the people of Pate Island were. Without mentioning the gold and silver, and their luxurious lifestyle, it would be difficult to understand the extent of their wealth. The loanwords fedha and dhahabu do not have their equivalents in Swahili, given that these concepts were newly introduced to the Swahili people by the Arabs. For this reason, the loanwords have an element of 
prestige. In the administration register, Inkishafi has a loanword mawaziri (waziri in singular form) in stanza 61. Here, the poet narrates that there once lived lords and ministers in the government who were always accompanied by a security detail. However, they are no longer alive, but buried in tiny, dusty and darkened graves. A government official of the position of minister is a powerful person who can have whatsoever he commands to be done. Ironically, death does not have respect even for the most powerful people. According to the poet, all the then powerful people of Pate, just like renowned scholars, jurists and prophets like King Solomon, are dead and buried in their graves. In Swahili, a minister or any person occupying a leadership position is referred to as kiongozi or msimamizi. The author chooses to use the loanword waziri because it is more prestigious compared to the Swahili words which are ordinary. Apart from prestige, the loanword waziri bears more weight in terms of the responsibility and power vested therein and has a specific connotation that is in tandem with the changed system of governance in Swahili society after the arrival of Arabs.

Sikate Tamaa (1980) is a collection of poems composed by Said A. Mohamed; and edited by Abdilatif Abdalla. The poems in Sikate Tamaa (Do not give up) centre around the reality of life in the world, highlighting suffering and oppression of the poor. Several of the poems discuss good and bad leadership in the third world countries especially after independence. Thematically, the poems can be categorized into two groups, namely political poems and poems about everyday life. In the political poems, the poet paints a picture of the ills rendered by leaders, corruption in particular, thus rebuking such leaders. For instance, in the poem "Nimeamka!" (I have woken up!), the poet says that he is now alert and will not be deceived again by those looting from him. The poet in "Ajabu" (Strange) shows how farmers who work hard in the fields do not enjoy the fruit of their labour; instead, the rich are the ones who benefit from the farmers' harvest. In the poem "Ukoloni na Ukolonimamboleo" (Colonialism and Neo-colonialism), the poet draws a comparison between colonialism and neo-colonialism, showing that the latter is worse than the former. This poem implies that African leadership is ruthless and wicked compared to the colonial masters. There are many poems about everyday matters such as not giving up in life in "Sikate Tamaa" (Do not give up), not to be choosy in job searching in "Mtu hachagui Kazi" (One does not choose a job) and oppression of women by men in "Imani ya Mwana" (Faith of a child). In terms of structure, the poet tries to deviate from traditional poetic structures.The poet in Sikate Tamaa uses the loanword shujaa in the poem "Namsifu Mwanamke" (In praise of woman). The word shujaa represents a hero who in most cases is a male person. Shujaa is a brave person or a warrior, who has gone through battles and came out victorious. In the African context, women never went to battle; they remained at home as their men went to the battlefront. In this poem, the poet depicts a woman warrior who is very brave 
despite traditional societal expectation. According to the poet, this woman is strong, firm, merciful, hard working and brave like a man. The poet uses the word shujaa in this poem to effectively explain the characteristics of this new African woman. In Swahili, an equivalent of shujaa is the word nguli. Despite having a Swahili word, the poet chose to use a loanword, for prestige reasons.

Bara Jingine (Another continent, 2001) is a collection of modern poems authored by Kithaka wa Mberia. It contains a total of thirty-four poems which are thematically categorized into two groups, namely poems on political and social topics, and poems to do with nature and environmental matters (Bertoncini 92). Structurally, the poems in Bara Jingine are composed in free verse and are generally short (Bertoncini 94). These are modern poems in Swahili as opposed to the traditional prosodic poems which are composed by adhering to the strict rules of equal stanzas, rhyme and meter. Modern poetry in Swahili is characterized by free verse, absence of rhymes and meter, and no equal number of stanzas in a verse. Thus, Bara Jingine is representative of modern Swahili poetry. Bertocini asserts that "Kithaka wa Mberia together with other East African contemporary poets has made a great contribution towards the renewal of the genre, proving that Swahili poetry is able to express universal themes and reach high artistic standards even without following traditional models" (103).

"Kikaoni Addis Ababa" (In a meeting in Addis Ababa) paints a picture of a meeting held by then presidents of African countries who met in the capital city of Ethiopia. This happened during the apartheid days in South Africa under the rule of P. W. Botha who also attended the meeting. In that meeting, all the African presidents rebuked the then president of South Africa for the violence and deaths suffered by poor South Africans of African descent. They lashed out at him for the innocent blood that was shed following the brutal shooting and killing of African school children in Soweto. "Jumapili ya Damu" (Bloody Sunday) is a poem that describes the kind of violence that takes place in African countries under military regimes. It paints a picture where shops are suddenly broken into and looted followed by gunshots and merciless killing of people. In this poem, the poet seems to allude to the regimes of former presidents Olusegun Obasanjo of Nigeria, Jean-Bedel Bokassa of the Central African Republic, Idi Amin Dada of Uganda, Mobutu Sese Seko of Zaire and Samuel Doe of Liberia. The poet finally longs for a day when African countries will be ruled by democratically elected leaders.

Social topics such as gender-based violence against women feature in certain poems (Bertoncini 92). The poem "Giza Mbele" (Darkness ahead), is a story of a schoolgirl who is abducted and raped on her way from school. As a result, the girl becomes pregnant and, cannot, therefore, proceed with her education. Likewise, "Pamela" is a poem that describes a young schoolgirl who is gang-raped and later drops out of school. Because of the rape, she goes mad and begins loitering in the market place naked. Different people in the community try to explain the predica- 
ment that has befallen Pamela—some saying it is God's wrath for her sins, others claiming it is witchcraft; while others suggest it is the ghost of her departed maternal uncle that is tormenting her.

Poems about the environment include "Ngao" (Shield), in which the poet-speaker laments that through his technological activities, man is slowly destroying the ozone layer, thus exposing himself to the harmful rays of the sun. In the poem "Mimi, Mto Nairobi" (I, River Nairobi), the poet paints a picture of River Nairobi, lamenting how Nairobi people are destroying the river. The river is dying due to its being harmed by waste in the form of oil, tins, tyres and all manner of garbage being dumped unto it. When people moved to Nairobi city, they found the river very clean and used its waters in their various activities. Now the river regrets the fact that even though it co-exists with Nairobi people, the people do not appreciate it in turn.

The poet of Bara Jingine has used loanwords from the economic register such as umiliki (possessions) and sokoni (in the market). In the third stanza of the poem "Jumapili ya Damu" the poet uses the loanword umiliki. Economic activity is suddenly disrupted by the violence caused by military regimes. Due to the military violence in the city, all the merchandise in the shops is looted, leaving the shopkeepers whose possessions have been looted poorer. Although the Swahili had possessions prior to the coming of Arabs, they seem to have no word for it. Therefore, this loanword was used for the reason of need; there is no Swahili word that can be used in its place. In part three of the poem "Pamela", the poet uses the loanword sokoni, in which he describes Pamela's life after her ordeal of being gang raped. According to the poet, Pamela resorts to a life of loitering in the market place after eventually becoming mad. Here, the irony is that a market is a place which is busy with economical activities, as people come to buy and sell. On the contrary, Pamela is not engaging in economical activities at the market because of her rape ordeal. The word sokoni which is used metaphorically, shows the effect of rape on Pamela. In other words, evil acts such as violence meted on women end up affecting women's economic power by derailing their studies and career development. Swahili has words for "market," that is, chete and gulio. However, the poet used the loanword sokoni, again for the reason of prestige. In this case, the loanword plays the role of decorating the poem for aesthetic purposes. It is also important to note that the Swahili words chete and ngulio are not used in everyday conversation of the speakers; instead, the words soko (market) and sokoni (in the market) are often used.

Adili na Nduguze (1952) is a novel authored by Shaaban Robert. It is a story of Adili whose brothers are jealous of him. The novel "is concerned with the virtue of charity, the criticism of futile jealousy and the lashing out of punishment that deforms the physical structure of human beings instead of reforming them morally" (Wafula 67). The loanword Adili is used for the main character of this novel. This word refers to something or someone righteous and morally upright. The narrator uses this name 
to portray the unquestionable character of this person called Adili. As a government officer, Adili maintains a high level of integrity in all that he does, and this is the theme being showcased through the main character. The virtue of being a good person had been in Swahili before the coming of the Arabs. The word that was used by Swahili people to refer to integrity is mwenendo mwema, which literarily means, good behavior or conduct. Thus, for prestige reasons, the author uses the loanword Adili, which has more weight in terms of integrity compared to the Swahili word.

Siku Njema (1996), literally translated as "Good Day", is a novel by Ken Walibora. It is a story about a young man known as Kongowea Mswahili, who was born to a talented taarab singer called Zainabu Makame. The loanword refers to a special kind of Swahili music whose melody is Arabian or Indian. Through the depiction of Mswahili's mother as a gifted taarab singer, the author depicts Swahili culture, because that type of music is a popular genre within it. This story shows that Zainabu Makame is a woman of integrity both in her private and public life as a taarab musician. In Swahili, there is no equivalent for taarab since this kind of music is a new concept that was introduced into Swahili culture. Even though the Swahili had their own types of music, there is no Swahili word that could be used to refer to taarab music. Hence, the loanword taarab serves both need and prestige reasons in this story.

My analysis of the literary texts has demonstrated that most loanwords were borrowed to cater for functional needs and prestige especially in the domains of commerce and religion. The examples given are just but a few of the many loanwords identified in the selected literary works. One could thus argue that literature enhances the idea of cultural integration through showcasing the Arabic words borrowed into Swahili.

\section{Conclusion}

Linguistic borrowing is a product of cultural contact among speakers of Swahili and Arabic. Moreover, this cultural contact has led to cultural integration from Arabic to Swahili which happened especially when the Swahili people embraced the Islamic faith. Apart from Islam, the Swahili also adopted Arabic culture into their own and borrowed their linguistic terms into the Swahili language, which are evident in Swahili literature. As witnessed above, the language used in Swahili literary works contains a lot of words borrowed from Arabic. Linguistic borrowing from Arabic to Swahili has led to the realisation of many Arabic words in Swahili. As such, Swahili has continued to enrich her vocabulary in many socio-cultural, religious and economic domains of society. Words borrowed from Arabic have become part and parcel of Swahili both in spoken and written forms. Thus, Arabic has enriched Swahili literature with its vocabulary, which is also integrated in Swahili culture. Linguistic borrowing can be said to have a significant contribution to the growth and development of Swahili. Swahili has benefited from Arabic vocabulary because of 
linguistic borrowing. It is through linguistic borrowing that Swahili contains many words from Arabic; and this is the reason many people mistake Swahili either to be an Arabic dialect, or to have Arabic origins. Hence, Swahili has ended up having a lot of cultural concepts in the spheres of religion, economics, education, socio- cultural, administration and literature borrowed from Arabic. The loanwords from Arabic are widely used by writers of Swahili literary works ranging from the novel, poetry, the short story and plays, as witnessed in the writings of Sayyid Abdalla A. Nasiri, Shaaban Robert, Said A. Mohamed, Kithaka wa Mberia and Ken Walibora, who use loanwords effectively in the writing of their literary texts.

\section{Works Cited}

Amidu, A. A. "Kiswahili: People, Language, Literature and Lingua Franca." Nordic Journal of African Studies vol. 4, no. 1, 1995, pp. 104-23.

Akidah, M. A. "A Lexical Phonology Study of Modern Standard Arabic (MSA)." Diss. U of Nairobi, 2012. http://erepository.uonbi.ac.ke/handle/11295/8456.

Bertoncini, E. Z. "Some Remarks on Kithaka wa Mberia's Poetry." Swahili Forum vol. 17, 2010, pp. 91-103.

Boesch, C. "Is Culture a Golden Barrier Between Human and Chimpanzee?" Evolutionary Anthropology vol. 12, no. 2, 2003, pp. 82-91. https://doi.org/10.1002/evan.10106.

Chiraghdin, S. and M. Mathias. Historia ya Kiswahili. Oxford U P, 1977.

Choge, S. C. "Fifty Years of Kiswahili In Regional and International Development." The Journal of Pan African Studies vol. 4, no. 2, 2012, pp. 172-203.

Gromov, M. "Women Characters in the Novels of Ken Walibora: Victims or Winners?" Pathways to African Feminism and Development. Journal of African Women Studies Center vol. 1, no. 3, 2015, pp. 1-13. http:// journals.uonbi.ac.ke/index.php/aws/article/view/1462.

Harries, L. "The Arabs and Swahili Culture." AFRICA vol. 34, no. 3, 1964, pp. 224-9.

Massamba, D. P. B., Y. M. Kihore and J. I. Hokororo. Sarufi Miundo ya Kiswahili Sanifu (SAMAKISA): Sekondari na Vyuo. Taasisi ya Uchunguzi wa Kiswahili (TUKI), 2004.

Mazrui A. A. and A. M. Mazrui. The Power of Babel: Language and Governance in the African Experience. James Curry, 1998.

Mohamed, S. A. Sikate Tamaa. Longman Kenya, 1980.

Mwaliwa, C. H. "An Analysis of the Syllable Structure of Standard Swahili Loanwords from Modern Standard Arabic." Diss. U of Nairobi, 2014. http://erepository.uonbi.ac.ke/handle/11295/77245.

Nasiri, S. A. A. Inkishafi. Longman Kenya, 1980.

Polome, E. Swahili Language Handbook. Center for Applied Linguistics, 1967.

Shaaban, R. Adili na Nduguze. Macmillan, 1952.

Walibora, K. Siku Njema. Longhorn, 1996.

wa Mberia, K. Bara Jingine. Marimba, 2001.

. "Al- Inkishafi: A Nineteenth Century Swahili Poem." International Journal of Liberal Arts and Social Sciences vol. 3, no. 3, 2015, pp. 91-101. http://erepository.uonbi.ac.ke/handle/11295/87114.

Wafula, R. M. "The Use of Allegory in Shaaban Robert's Prose Works." Diss. U of Nairobi, 1989. http:// erepository.uonbi.ac.ke/handle/11295/23810.

Wamitila, K.W. "Reading the Kenyan Swahili Prose Works: A Terra Incognita in Swahili Literature". AAP vol. 51, 1997, pp. 117-25. 
Inkishafi

Kiswahili

Askari

Bidhaa

Bismillahi

Dhahabu

Dhambi

Dhiki

Dini

Dunia

Enzi

Fasihi

Fedha

Hadithi

Haki

Hali

Hela

Inkishafi

Jahanam

Kalamu

Khasara

Marashi

Mola

Mtume

Safari

Sala

Salamu

Sanaa

Shetani

Toba

Ubeti

Utenzi

Wahakiki

Washairi

Waziri

\section{Gloss}

Guard

Product

In the name of God

Gold

Sin

Distress

Religion

World

Era

Literature

Silver

Story

Justice

Condition

Money

Soul-searching

Hell

Pen

Loss

Perfume

God

Prophet

Journey

Prayer

Greeting

Art

Satan

Repentance

Stanza

Narrative poem

Critics

Poets

Minister
Sikate Tamaa

Ari

Zeal

Asubuhi

Morning

Dawa

Dhamana

Fahari

Medicine

Surety

Pride

Fasihi

Literature

Ghali

Haba

Hadaa

Hadithi

Hotuba

Huria

Imani

Jahanamu

Kiburi

Kubariki

Kufisidi

Madaraka

Mali

Mashariki

Mdhamini

Milele

Nielimike

Raha

Roho

Sanaa

Shujaa

Tamaa

Thabiti

Thamani

Ubeti

Utawala

Utenzi

Wahakiki

Washairi

Watukufu
Expensive

Little

Deceive

Story

Speech

Free

Faith

Hell

Pride

To bless

To destroy

Power

Wealth

East

Guarantor

Forever

To be educated

Comfort

Spirit

Art

Hero

Greed

To be firm

Value

Stanza

Rule

Narrative Poem

Critics

Poets

Glorious people 
Bara Jingine

\begin{tabular}{ll} 
Aibu & Shame \\
Amani & Peace \\
Amri & Order \\
Barafu & Ice \\
Binadamu & Human being \\
Bunduki & Rifle \\
Dhiki & Distress \\
Dhulumiwa & Oppressed \\
Enzi & Era \\
Fasihi & Literature \\
Ghadhabu & Wrath \\
Habari & News \\
Hadithi & Story \\
Hayawani & Beast \\
Kahawa & Coffee \\
Maduka & Shops \\
Maghala & Store rooms \\
Mahadhi & Rhythm \\
Mashairi & Poems \\
Mauti & Death \\
Msafiri & Traveller \\
Sanaa & Art \\
Serikali & Government \\
Siasa & Politics \\
Sokoni & In the market \\
Sura & Chapter \\
Tabasamu & Smile \\
Taifa & Nation \\
Taratibu & Slowly \\
Tiba & Medical treatment \\
Ubeti & Stanza \\
Ufisadi & Corruption \\
Ufukara & Poverty \\
Umiliki & Possessions \\
Utafiti & Research \\
Utenzi & Epic Poem \\
Viwanda & Industries \\
Wahakiki & Critics \\
Walimu & Teachers \\
Washairi & Poets \\
\hline &
\end{tabular}

Adili na Nduguze

\begin{tabular}{|c|c|}
\hline Adili & Moral \\
\hline Almasi & Diamond \\
\hline Amirijeshi & Commander \\
\hline Ardhi & Land \\
\hline Arobaini & Forty \\
\hline Birika & Kettle \\
\hline Daftarini & In an exercise book \\
\hline Dola & State \\
\hline Faida & Profit \\
\hline Gharama & Cost \\
\hline Habari & News \\
\hline Harusi & Wedding \\
\hline Hasidi & Malicious \\
\hline Hazina & Treasure \\
\hline Imamu & Imam \\
\hline Ishara & Sign \\
\hline Ishirini & Twenty \\
\hline Karibu & Welcome \\
\hline Lugha & Language \\
\hline Maalum & Special \\
\hline Madiwani & Councillors \\
\hline Mali & Wealth \\
\hline Maradhi & Disease \\
\hline Mashuhuri & Famous \\
\hline Mfalme & King \\
\hline Mwadilifu & Moral person \\
\hline Nahodha & Captain \\
\hline Naibu & Deputy \\
\hline Rai & Plead \\
\hline Sanifu & Skilled \\
\hline Sheria & Law \\
\hline Sifa & Praise \\
\hline Starehe & Comfort \\
\hline Suluhu & Solution \\
\hline Tabia & Behaviour \\
\hline Taji & Crown \\
\hline Tamasha & Festivity \\
\hline Thuluthi & A third \\
\hline Walikariri & They recited \\
\hline Waziri & Minister \\
\hline Yamkini & Probably \\
\hline
\end{tabular}


Siku Njema

Alhamdulilahi

Almuradi

Praise be to God

Amirijeshi

So long as

Darubini

Commander

Dola

Telescope

Dua

State

Elimu

Prayer

Ghadhabu

Education

Gharama

Wrath

Haramu

Cost

Hasidi

Illegitimate

Hayati

Malicious

Husudu

Deceased

Inshallah

Envy

Jazba

God willing

Joho

Emotion

Kahaba

Robe

Madiwani

Prostitute

Maelfu

Councillors

Makala

Thousands

Maktaba

Article

Mfalme

Library

Mwanaharamu

King

Naam

Illegitimate child

Naibu

Yes

Rafiki

Deputy

Rasilmali

Friend

Rubani

Assets

Saumu

Pilot

Sheria

A fast

Sukari

Law

Taarab

Sugar

Takriban

Taarab music

Almost

Taswira

Imagery

Umma

Public

Ushairi

Poetry

Wakati

Time

Yamini

Oath 